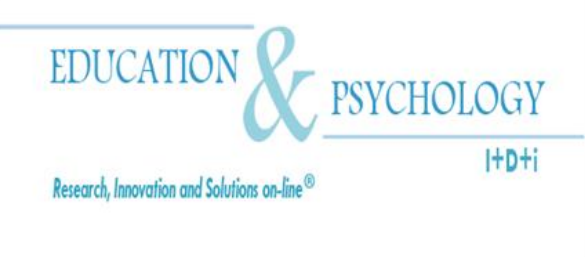

\title{
The Influence of Experience and Cognitive Style on International Entrepreneurial Intentions: The Contribution of Academic Education in this Relation
}

\section{Lutz Sommer}

${ }^{1}$ Department of Business Administration and Engineering, Albstadt-Sigmaringen University

\section{Germany}

Correspondence: Lutz Sommer. Jakobstrasse 1 - 6, 72458 Albstadt, Germany.

E-mail: sommer@hs-albsig.de

(C) Education \& Psychology I+D+i and Editorial EOS (Spain) 


\begin{abstract}
Introduction. The paper at hand examines the influence of Cognitive Style (CS) and International Experience (IE) on International Entrepreneurial Self-Efficacy (IESE) and International Entrepreneurial Intention (IEI) as well as the role of Academic Education (AE) in this context.

Method. Based on a survey that was conducted among 111 students the hypotheses were verified by means of various structural equation models.

Results. The results showed that IE significantly influences IEI whereas the influence of CS on IEI is significant in none of the models. IESE is neither influenced by IE nor by CS.

Discussion. The following conclusions can be drawn: (1) Both Cognitive Styles (CS), analytical as well as intuitive, have to be promoted in Academic Education; (2) Further research is need in measuring Cognitive Style (CS); (3) Existing IE acquired in Academic Education can make an important contribution to overcome obstacles in the formation of IEIs; (4) In contrary to Ajzen (1985) experience can be more than a background factor in contexts like international entrepreneurship.
\end{abstract}

Keywords: International Entrepreneurship, Cognition, International Experience, Theory of Planned Behavior, Academic Education.

Received: 03/13/13 Initial acceptance: 04/10/13 Final acceptance: 07/18/13 


\section{La Influencia de la Experiencia y el Estilo Cognitivo en las Intenciones de Emprendimiento Internacional: la Aportación de la Educación Académica en esta Relación}

\section{Resumen}

Introducción. El informe examina la influencia del estilo cognitivo (CS) y la Experiencia Internacional (IE) de Autoeficacia Emprendedora Internacional (IESE) y la intención emprendedora Internacional (IEI), así como el papel de la educación académica (AE) en este contexto.

Método. Basado en una encuesta realizada entre 111 estudiantes de las hipótesis fueron vercado por medio de diversos modelos de ecuaciones estructurales.

Resultados. Los resultados mostraron que el IE influye significativamente IEI mientras que la influencia de la CS en IEI no es significativa en ninguno de los modelos. IESE no se ve influenciada por el IE ni por CS.

Discusión. Los siguientes se pueden sacar conclusiones: (1) Los dos estilos cognitivos (CS), analíticos, así como intuitivos, deben ser promovidos en la educación académica; (2) Se necesita investigación adicional para medir el efecto del Estilo Cognitivo (CS); (3 ) la IE adquirida en la formación académica pueden hacer una importante contribución para superar los obstáculos en la formación de IEIs; (4) en contra de Ajzen (1985), la experiencia puede ser más que un factor de fondo en contextos como el espíritu empresarial internacional.

Palabras clave: Emprendimiento Internacional, Cognición, Experiencia Internacional, Teoría del comportamiento planificado, Educación Académica. 


\section{Introduction}

\section{Intention, Cognition and Experience}

Studies on Entrepreneurial Cognition exist in many forms (e.g. Barbosa, Gerhardt \& Kickul, 2007; Hird, 2012; Katz \& Shepherd, 2003; Urban, 2012). The variety and topicality of the publications shows that this subject matter is still under discussion. Part of this discussion deals with the question as to what possible meaning Cognitive Style (CS) could have in the context of the development of entrepreneurial self-efficacy or entrepreneurial intention (Kickul, Gundry, Barbosa, \& Whitcanack, 2009, p. 440). This question inevitably leads to the Theory of Planned Behavior (TPB) by Ajzen (1985; 1991; 2005), in which this represents the relationship between Attitude, Social Norm and Perceived Behavioral Control over intention and the role of background factors like experience (Ajzen, 2005, p. 135). These background factors lead to question, whether some factors like experience are more than a background factor, which is widely discussed in literature (Sommer, 2011) and also still under discussion. In the following we have to define the terms "Intention, Cognitive Style and Experience". Finally, the role of Academic Education (AE) should be discussed in this context. Following Ajzen (1985; 1991), "Intention" can be defined as follows: “... self-predictions, that is, the individual's estimate of the likelihood that he/she will actually perform the critical behavior" (Gollwitzer, 1993, p. 147).

Cognitive Style (CS) as a concept has not been clearly defined even in literature. Kickul et al. (2009) attempt to define the concept as follows: “...cognitive style is generally thought of as a phenomenon with multiple dimensions, including decision making, learning, personality, and awareness [Leonard, Beauvais, \& Scholl, 2005] ...this dimension can be conceptualized as a continuum ranging from intuitive to analytic" (Kickul et al., 2009, p. 441). This approach to the definition completes Olsen's observations (1985) on the subject of "linear sequential processing of information" (Kickul et al., 2009, p. 441) and will be addressed in this work, since it represented the basis for studies made by Kickul et al. (2009). Sanchez et al. (2011) choose to adopt another approach to the definition, according to which they defined Cognitive Style as "... the way people perceive environmental stimuli and how they organize and use information from their environment to guide their actions" (Sánchez et al., 2011, p. 435). With regard to entrepreneurial self-efficacy recourse is also made, within 
the framework of the comparability of the study findings, to the definition approach made by Kickul et al. (2009), who, following Bandura (1997), defined as follows: “...as people's judgements of their capabilities to organize and execute courses of actions required to attain designated types of performance" (Kickul et al., 2009, p. 441).

With regard to the concept of Experience or International Experience (IE), there is also a variety of definitions. Therefore, to simplify matters, recourse will be made to a generally recognised definition from the Oxford University Press, which defines experience as follows:“ ...the knowledge or skill acquired by a period of practical experience of something, especially that gained in a particular profession" (Oxford University Press, 2013). Alternatively, the University of Cambridge defines experience as follows in its dictionary: “... the process of getting knowledge or skill from doing, seeing or feeling things" (Cambridge University Press, 2013). For the purposes of this study, International Experience (IE) - in contrast to Bandura (1994) - should be observed from a superordinate level, i.e. not only as an IE which refers to entrepreneurship, but as an IE in the overall context of entrepreneurship, for example intercultural experience.

\section{Relationship - Intention, Cognition, Experience and Academic Education}

In the next step it is necessary to investigate the possible relationship between "Intention, Cognitive Style and Experience" and the role of Academic Education (AE). The Theory of Planned Behavior by Ajzen offers an interesting approach in this context (1985; 1991; 2005). In this model, background factors are named in addition to the constructs mentioned, such as experience and also intelligence (Ajzen, 2005, pp. 134 et seqq.). If the Ajzen model (1985) is linked to the question raised by Kickul et al. (2009) as to the meaning of Cognitive Style (CS) with regard to entrepreneurial self-efficacy and the entrepreneurial intention following on from it, the question must be asked as to where Cognitive Style (CS) can be classified within the framework of TPB. Within the framework of this study, the assumption should be made that the Cognitive Style can be seen as a background factor. In addition to the scientific discussion on the meaning of Cognitive Style, another scientific discussion is held on the meaning that can be attributed to experience in relation to entrepreneurship (e.g. Sommer, 2010). Both scientific discussions are related to Ajzen's TPB model (1985), since Cognitive Style (CS) and also experience are components of the model in the form of background factors (Ajzen, 2005, p. 135). The subject of the present studies should pose the question as to which possible influence both background factors have on entrepreneurial self-efficacy or the 
entrepreneurial intention following it. Studies already existing on the subject of entrepreneurship by Kickul et al. (2009) focussing on Cognitive Style (CS), and by Sommer (2010; 2011) focussing on International Experience (IE), should be summarised in a new study in which both aspects are modelled.

Another discussion deals with the relation between creativity and entrepreneurial intentions on the one hand and the role Academic Education (AE) in this context on the other hand. Hamidi, Wennberg and Berglund (2008) state: “...the role of creativity for entrepreneurial intentions also have implications for entrepreneurship education" (Hamidi et al., 2008, p. 317). The authors identified a positive relation (Hamidi et al., 2008). De la Fuente, Vera, and Cardelle-Elawar (2012) emphasise the necessity to integrate entrepreneurships into academic education, such as education at English universities has shown (De la Fuente et al., 2012). Bandura (1994) described the connection between self-efficacy, experience and intention: "...the most effective way of creating a strong sense of efficacy is through mastery experience” (Bandura, 1994). Sander and Sanders (2003) make comparable findings: “...successful experience resulting in higher levels of self-efficacy" (Sander \& Sanders, 2003, p. 3). Both statements accentuate the meaningfulness of experience, which seems to make an examination of a more intensive integration into Academic Education (AE) meaningful.

\section{Research Question and Hypotheses}

The research question with its focus on international entrepreneurship can be formulated as follows, based on the above statements and on work carried out by Kickul et al. (2009): Based on a random sample of students with different international backgrounds, a study will be carried out on the extent to which Cognitive Style (CS / Latent Variable - Exogenous), according to Kickul et al. (2009), influences International Entrepreneurial SelfEfficacy (IESE / Latent Variable - Endogenous) or International Entrepreneurial Intentions (IEI / Latent Variable - Endogenous) in the sense of Kickul et al. (2009). For this purpose, hypotheses studies by the authors will be used, according to which ,...individuals who prefer the intuitive style of information processing reported higher self-efficacy beliefs regarding the tasks included in the searching stage ... which were associated with their intentions" (Kickul et al., 2009, p. 448), whereas “...individuals with the analytic preferred mode of thinking reported greater entrepreneurial self-efficacy for the planning, marshalling of resources, and implementation stages" (Kickul et al., 2009, p. 448). 
Furthermore, a study will be made on the influence of the surveyed students' international background or International Experience (IE / Latent Variable - Exogenous) with regard to International Entrepreneurial Intention (IEI / Latent Variable - Endogenous) or International Entrepreneurial Self-Efficacy (IESE / Latent Variable - Endogenous). Regarding International Experience (IE), reference can be made to the Theory of Planned Behavior by Ajzen $(1985 ; 1991 ; 2005)$, according to which experience generally functions as a background factor which affects the determinants of the intention through beliefs (Ajzen, 2005). Referring to the present object of study, International Experience (IE) should be regarded as a determinant of the IEI, whereby the IEI in the sense of Ajzen's model (2005) is not influenced directly by International Experience (IE), as Ajzen (2005) ascertains: “...when these determinants were statistically controlled, the background factors no longer correlated significantly with intentions“(Ajzen, 2005, p. 136). As I have already discussed in various articles, there are in general diverging estimates with regard to the relationship between experience and intentions (e.g. Albarracín \& Wyer, 2000; Hsu \& Lu, 2004; Kim, Choi, \& Han, 2009; Ouellette \& Wood, 1998; Pomery, Gibbons, Reis-Bergan, \& Gerrard, 2009; Sheeran \& Orbell, 1999) and International Experience (IE) and intention in particular (Sommer, 2011, Sommer, 2012, Sommer, 2013).

In conclusion, it should be questioned whether Academic Education (AE) can play a role in this connection. Following Kickul et al. (2009) and the above statements on International Experience (IE), the following hypotheses can now be derived (cf. Kickul et al., 2009, pp. 443-445):

Hypothesis Hla: There is a positive relationship between International Entrepreneurial Self-Efficacy (IESE) with regard to the "Searching Stage" and the International Entrepreneurial Intention (IEI) in the group of students studied (Kickul et al., 2009, p. 443). Hypothesis H1b: The students' Cognitive Style (CS) influences IESE and IEI with regard to the "Searching Stage" (Kickul et al., 2009, p. 443).

Hypothesis HIc: The students' International Experience (IE) influences IESE and IEI with regard to the "Searching Stage".

Hypothesis H2a: There is a positive relationship between International Entrepreneurial Self-Efficacy (IESE) in relation to the „Planning Stage“ and the International Entrepreneurial Intention (IEI) in the group of students studied (Kickul et al., 2009, p. 443). Hypothesis H2b: The students' Cognitive Style influences IESE and IEI with regard to the „Planning Stage“ (Kickul et al., 2009, p. 443). 
Hypothesis H2c: The students' International Experience (IE) influences IESE and IEI with regard to the „Planning Stage“.

Hypothesis H3a: There is a positive relationship between International Entrepreneurial Self-Efficacy (IESE) with regard to the „Marshalling Stage“ and the International Entrepreneurial Intention (IEI) in the group of students studied (Kickul et al., 2009, p. 444).

Hypothesis H3b: The students' Cognitive Style (CS) influences IESE and IEI with regard to the „Marshalling Stage“ (Kickul et al., 2009, p. 444).

Hypothesis H3c: The students' International Experience (IE) influences IESE and IEI with regard to the „Marshalling Stage“.

Hypothesis H4a: There is a positive relationship between International Entrepreneurial Self-Efficacy (IESE) with regard to the "Implementation Stage" and the International Entrepreneurial Intention (IEI) in the group of students studied (Kickul et al., 2009, p. 445).

Hypothesis H4b: The students ' Cognitive Style influences IESE and IEI with regard to the "Implementation Stage" (Kickul et al., 2009, p. 445).

Hypothesis H4c: The students' International Experience (IE) influences IESE and IEI with regard to the „Implementation Stage“.

\section{Method}

\section{Participants}

National and international students $(\mathrm{n}=210)$ in the $7^{\text {th }}$ term of bachelor studies or 2 nd term of master studies were surveyed during the period 2011 - 2012 at the AlbstadtSigmaringen University in Baden-Württemberg (Campus Albstadt). These were students from the industrial engineering course who had been trained in technology and business with an international orientation and finish their bachelor or master studies in 2013, or in other words were close to making a decision on their professional future. Furthermore, international students $(n=80)$ whose courses focussed on economics and international orientation from the Cross-Cultural Management Erasmus Intensive Programme of the European Union (European University Cyprus, 2009) were surveyed; these students also finish their study in 2013. In total, $\mathrm{n}=290$ students were surveyed, 133 responded and 111 responses were included in the evaluation (= response rate of $38,3 \%$ ) with the following characteristics: (1) The average age of the participants was 24 years; (2) The following countries of origin were indicated by the 
students: Germany (51\%), Portugal (6\%), Lithuania (6\%), Brazil (5\%), Greece (4\%), Cyprus (4\%), Malaysia (4\%), Korea (3\%), Russia (3\%), India (3\%), Turkey (3\%), Other (8\%); (3) Percentage of students with International Experience (IE) of more than 6 months: 48,6 \%; (4) The proportion of females was $48 \%$.

\section{Sampling Procedure, Sample Size and Measures}

The basis for the study are different surveys carried out between 2011 and 2012 among German students at the Albstadt-Sigmaringen University and international students from different European universities, who participated in the Cross-Cultural ManagementErasmus Intensive Programme ${ }^{1}$ (European University Cyprus, 2009). In all studies carried out, care was taken to make sure that participation was on a voluntary basis and that the evaluation of the data would be treated in a confidential manner. As instrument a questionnaire was used. This was comprised of 61 items, divided into four blocks, which could be responded to in $15-20$ minutes.

In the first part, 6 items were used to investigate Personal Background (PB) whereby items (PB-1.1 to $1.5,1.9$ ) were of a very general nature, in other words, not verifiable from any specific source. Using three further items (IE-1.6 to IE-1.8), data was collected on the international Personal Background (PB) in particular, or International Experience (IE) of the persons surveyed, as students or employees on the one hand, and IE abroad for other reasons (also not verifiable from any specific source, yet comparably with Schmid \& Kretschmer, 2005; Sommer, 2012). Specific examples of international entrepreneurial experience are not collected, since these as a rule do not exist where students are involved. Within the scope of this study, IE are superior experiences in an international environment. Due to redundancies and inaccurate dates (e.g. years instead of months) in the responses concerning the IE as a student (item IE-1.8) or employee (item IE-1.7) on the one hand and the IE for other reasons (item IE-1.6) on the other hand, only two items were evaluated for the IE that documented the IE as student (IE-1.8) and employee (IE-1.7). The value 1 represents no International Experience (IE), the value 2 represents International Experience (IE) of more than a half year. The third item (IE-1.6) was used as a plausibility check. Further details can be found in appendix.

\footnotetext{
${ }^{1}$ The distribution and collection of the questionnaires in Cyprus was carried out locally by the Bachelor student Oliver Kiefer who earned his Bachelor's Degree in 2011 at the Albstadt-Sigmaringen University
} 
In the second part data was collected on the basis of the questionnaire set up by Kickul et al. (2009), which in turn was based on work by Cox et al. (2002) (Kickul et al., 2009, p. 446), an International Entrepreneurial Self-Efficacy with 10 items (Kickul et al., 2009, p. 450), whereby the items were adapted to the international context by reformulation (see appendix). The value 1 of the Likert scale used documents a low level of confidence and the value 7 a high level of confidence (Kickul et al., 2009, p. 446).

In the third part, 4 items were collected for an International Entrepreneurial Intention, which also were based on the modification of items from Kickul et al. (2009) and Crant (1996), (Kickul et al., 2009, p. 446). The Likert scale was also used here, whereby the value 1 documents a low level of agreement with the statement and the value 7 a high level of agreement (Kickul et al., 2009, p. 447).

The fourth part of the survey followed recommendations made by Kickul et al. (2009) in part, oriented on the Cognitive Style Index (CSI) by Allinson and Hayes (1996). The questionnaire was based on 38 items $^{2}$, encrypted correspondingly by the authors (C. Allinson, personal communication, January 11, 2010; Allinson \& Hayes, 1996; Kickul et al., 2009). Due to the key being sent by the above author (C. Allinson, personal communication, January 11, 2010) a check could be made as to whether the persons surveyed, with regard to the Cognitive Style (CS), were to be allocated to the analytical or rather to an intuitive style. According to C. Allinson (personal communication, January 11, 2010), 2 points were to be given for the correct response (True) 0 points for incorrect responses (False) and 1 point for the category "don’t know" (C. Allinson, personal communication, January 11, 2010). A high total CSI value indicates more of an analytical Style, a low value an intuitive Style (C. Allinson, personal communication, January 11, 2010). Deviating from the study by Kickul et al. (2009), who evaluated "True" with 1 point and "False" with 0 points, and in addition had carried out an extraction factor (Kickul et al., 2009, p. 445), the present empirical study was carried out on the basis of recommendations made by C. Allinson (personal communication, January 11, 2010). The following table gives an overview of the items used (see also appendix):

\footnotetext{
${ }^{2}$ The 38 items used may not be replicated, in accordance with instructions from the author, but could be sent upon request (C. Allinson, personal communication, January 11, 2010) 
Table 1. Overview of Questionnaire Structure

\begin{tabular}{|c|c|c|c|c|c|}
\hline $\begin{array}{l}\text { Question } \\
\text { Numbers }\end{array}$ & Item Name & $\begin{array}{l}\text { Construct } \\
\text { Name }\end{array}$ & $\begin{array}{l}\text { Construct } \\
\text { Measured }\end{array}$ & Scale & Source \\
\hline $\begin{array}{c}1,2,3,4,5 \text { and } \\
9\end{array}$ & $\begin{array}{c}\text { PB } 1.1-\mathrm{PB} 1.5 \text { and PB } \\
1.9\end{array}$ & $\mathrm{~PB}$ & $\begin{array}{l}\text { Personal Back- } \\
\text { ground }\end{array}$ & various & unknown / unspecific \\
\hline $6,7,8$ & IE 1.6 - IE 1.8 & IE & $\begin{array}{l}\text { International } \\
\text { Experience }\end{array}$ & $1-2$ & $\begin{array}{c}\text { (c.f. Schmid } \\
\text { \& Kretschmer, 2005; } \\
\text { c.f. Sommer, 2012) }\end{array}$ \\
\hline $10-19$ & IESE 2.1 - IESE 2.10 & IESE & $\begin{array}{l}\text { International } \\
\text { Entrepreneurial } \\
\text { Self-Efficacy }\end{array}$ & $1-7$ & $\begin{array}{c}\text { (Kickul et al., } 2009 \\
\text { based on Cox et al., } \\
\text { 2002) }\end{array}$ \\
\hline $20-23$ & IEI 3.1 - IEI 3.4 & IEI & $\begin{array}{l}\text { International } \\
\text { Entrepreneurial } \\
\text { Intention }\end{array}$ & $1-7$ & $\begin{array}{c}\text { (Crant, 1996; Kickul et } \\
\text { al., 2009) }\end{array}$ \\
\hline $24-61$ & CSI 4.1 - CSI 4.38 & CSI & $\begin{array}{l}\text { Cognitive Style } \\
\text { Index }\end{array}$ & $1-3^{*}$ & $\begin{array}{l}\text { (C. Allinson, personal } \\
\text { communication, Janua- } \\
\text { ry } 11 \text { 2010; Allinson } \\
\& \text { Hayes, 1996; Kickul } \\
\text { et al., 2009) }\end{array}$ \\
\hline
\end{tabular}

* Reverse scoring

Note. Table by this author

The following values resulted from items included in the study (Mean / Std. Deviation):

Table 2. Item deviation values

\begin{tabular}{lll}
\hline Item & Mean & $\begin{array}{l}\text { Std. De- } \\
\text { viation }\end{array}$ \\
\hline IE-1.7 & 1.26 & 0.441 \\
IESE-2.1 & 4.03 & 1.304 \\
IESE-2.2 & 4.59 & 1.275 \\
IESE-2.3 & 4.23 & 1.272 \\
IESE-2.4 & 4.29 & 1.337 \\
IESE-2.5 & 3.99 & 1.318 \\
IESE-2.6 & 4.38 & 1.431 \\
IESE-2.7 & 4.32 & 1.368 \\
IESE-2.8 & 4.70 & 1.283 \\
IESE-2.9 & 4.63 & 1.375 \\
IESE-2.10 & 4.42 & 1.431 \\
IEI-3.1 & 3.83 & 1.757 \\
IEI-3.2 & 3.09 & 1.564 \\
IEI-3.3 & 4.16 & 1.886 \\
IEI-3.4 & 3.99 & 1.947 \\
CSI-Score & 42.64 & 9.375 \\
\hline
\end{tabular}

Note. Table by this author 
IBM Statistics Software SPSS 19 and AMOS 20 were used to analyse the data. The latter is used to display Linear Structural Equation Models, which served as a statistical basis for this study. The following variables (Endogenous / Exogenous) were used (c.f. Weiber \& Mühlhaus, 2010):

1) Variable International Entrepreneurial Self-Efficacy (IESE / Latent Variable - Endogenous); 10 items were collected (see appendix), based on the four stages according to model by Kickul et al. (2009) (Kickul et al., 2009, p. 450): (1) Searching Stage consisting of item IESE-2.1 and 2.2; (2) Planning Stage consisting of item IESE-2.3 and 4; (3) Marshalling Stage consisting of IESE-2.5 to IESE-2.8; (4) Implementing Stage consisting of item IESE2.9 and 10.

2) Variable International Entrepreneurial Intention (IEI / Latent Variable - Endogenous); was collected through the items IEI-3.1 to IEI-3.4 (see appendix) according to Kickul et al. (2009).

3) Cognitive Style (CS) / Cognitive Style Index (CSI / Latent Variable - Exogenous); acquired through items CSI-1 to CSI-38 (see appendix) according to C. Allinson (personal communication, January 11, 2010)

4) International Experience (IE / Latent Variable - Exogenous) acquired through items IE 1.7 and IE 1.8 .

\section{Results}

Statistics and data analysis

At first carrying out a reliability test, followed by validity test and finished with a fit test of the research models 1,2, 3 and 4 is a proper handling of the statistics and data analysis according to Weiber and Mühlhaus (2010).

Carrying out the reliability test on the basis of an Exploratory Factor Analysis (EFA) takes place based on recommendations made by Weiber and Mühlhaus (2010). For this purpose, the MSA value (Measure of Sampling Adequacy), Communalities and their KMO Value (Kaiser-Meyer-Olkin criterion) were calculated, and the Bartlett Test carried out (Weiber \& Mühlhaus, 2010): 
Table 3. Review of criteria for one-dimensional item structure

\begin{tabular}{lcc}
\hline Criteria & Guidelines & Sample \\
\hline MSA & $\geq 0.5$ & $100 \%$ satisfied $*$ \\
Communalities & $\geq 0.5$ & $100 \%$ satisfied $*$ \\
KMO criterion & $\geq 0.6$ & 0.827 \\
Bartlett Test & $\mathrm{p}=0$ & 0.000 \\
\hline
\end{tabular}

* Percentage of variables that met the threshold

Note. According to Weiber \& Mühlhaus, 2010; Table by this author

Furthermore, the test of indicator and construct reliability was carried out using Cronbach's Alpha at the construct level and the CITC Value (Corrected Item-to-total Correlation) calculated at indicator level (Weiber \& Mühlhaus, 2010):

Table 4. Review of criteria for indicator and construct reliability

\begin{tabular}{lcc}
\hline Criteria & Guidelines & Sample \\
\hline Cronbach's alpha & $\geq 0.7$ & 0.880 \\
KITK & $\geq 0.5$ & $75 \%$ satisfied * \\
\hline
\end{tabular}

* Percentage of variables that met the threshold

Note. According to Weiber \& Mühlhaus, 2010; Table by this author

The results show that all items fulfilled the first criterion and that only a few items did not fulfil the second criterion, in part marginally, so that all items remained in the random sample.

The validity test is unnecessary, due to the fact that the items were checked for validity by the authors (e.g. Kickul et al., 2009) and have already been tested in practice. Study models are based on the hypotheses 1 to 4 , whereby four models - 1 to 4 - were generated, following the four stages of Entrepreneurial Self-Efficacy (Kickul et al., 2009, p. 450). The following variables were used for the path diagram:

\section{Table 5. Explanation of variables}

\begin{tabular}{llll}
\hline Latent variable - Exogenous & Measured variable / item & Residual variable \\
\hline CSI: & Cognitive Style Index & CSI-Score & e1 \\
IE: $\quad$ International Experience & IE-1.7, IE-1.8 & e5, e6 \\
\hline Latent variable - Endogenous & Measured variable / item & Residual variable \\
\hline IESE: International Entrepreneurial & IESE-2.1 to IESE-2.10 & e2-e4, e7 \\
. $\quad$ Self-Efficacy & & e9-e11, e8 \\
IEI: International Entrepreneurial & IEI-3.1 to IESE-3.4 & \\
. Intention & & \\
\hline \multicolumn{5}{c}{ Note. According to Weiber \& Mühlhaus, 2010; Table by this author }
\end{tabular}


The following assumptions underlie the four models (Weiber \& Mühlhaus, 2010):

1) Variables CSI and IE are exogenous, because they have an explanatory nature.

2) Variable IESE and IEI are influenced by the variables (constructs) and are therefore endogenous variables.

3) The items CSI-Score, IESE-2.1, IESE-2.3, IESE-2-6, IESE-2.9, IE-1.8 and IEI-3.1 are reference indicators respectively fixed parameters. The path coefficient is therefore set to 1 .

4) The regression weight of the error terms was defined with 1 . The variance of the single item construct CSI-Score is set to 0 (Weiber \& Mühlhaus, 2010, p. 153)

The following figures illustrate the research model 1 (Searching Stage), 2 (Planning Stage), 3 (Marshalling Stage) and 4 (Implementing Stage) in accordance with recommendations made by Kickul et al. (2009). Scope of work is: (1) To confirm or disconfirm the influence of International Experience (IE) with regard to International Entrepreneurial Intention (IEI) or International Entrepreneurial Self-Efficacy (IESE) based on the different stages by Kickul et al. (2009); (2) To examine whether or not Academic Education (AE) can play a relevant role in this context.

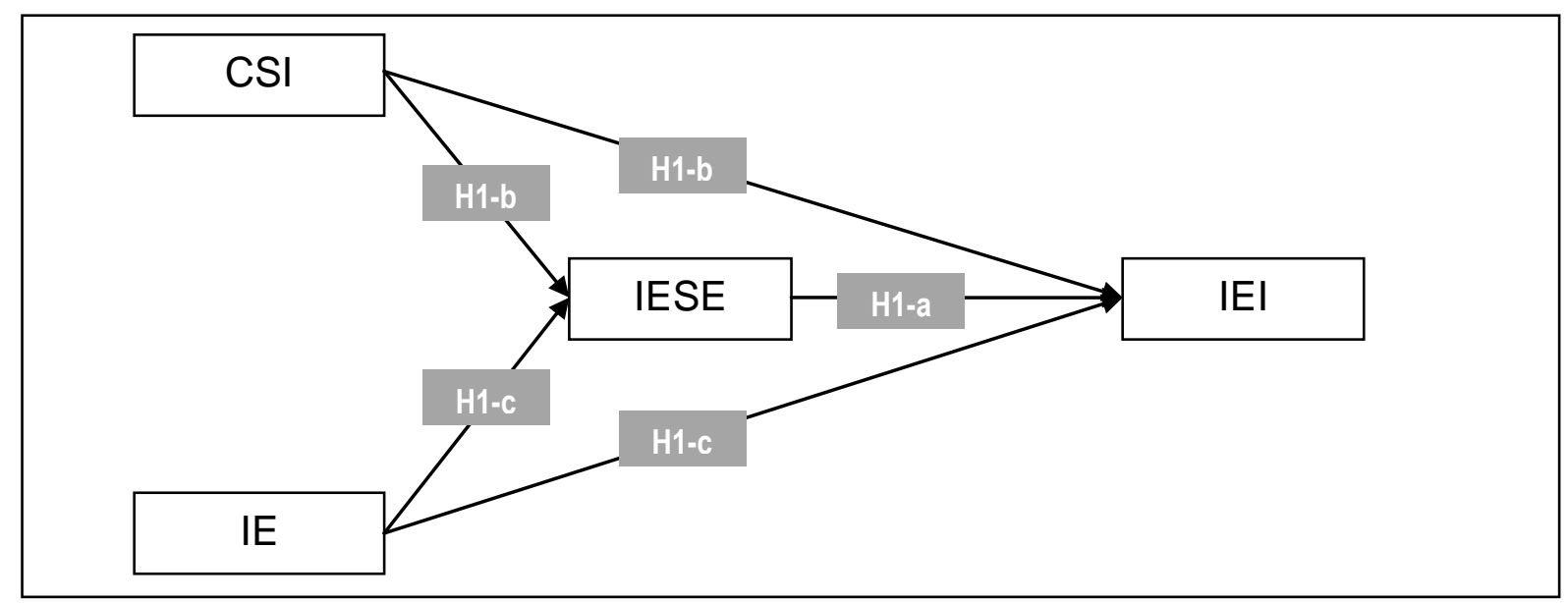

Figure 1. Research Model 1 (Searching Stage) partly based on Kickul et al. (2009); Sample of 111 students;

CSI = Cognitive Style Index according to Allinson \& Hayes (1996); IE = International Experience; IESE = International Entrepreneurial Self-Efficacy and IEI = International Entrepreneurial Intention (cf. Kickul et al., 2009) 


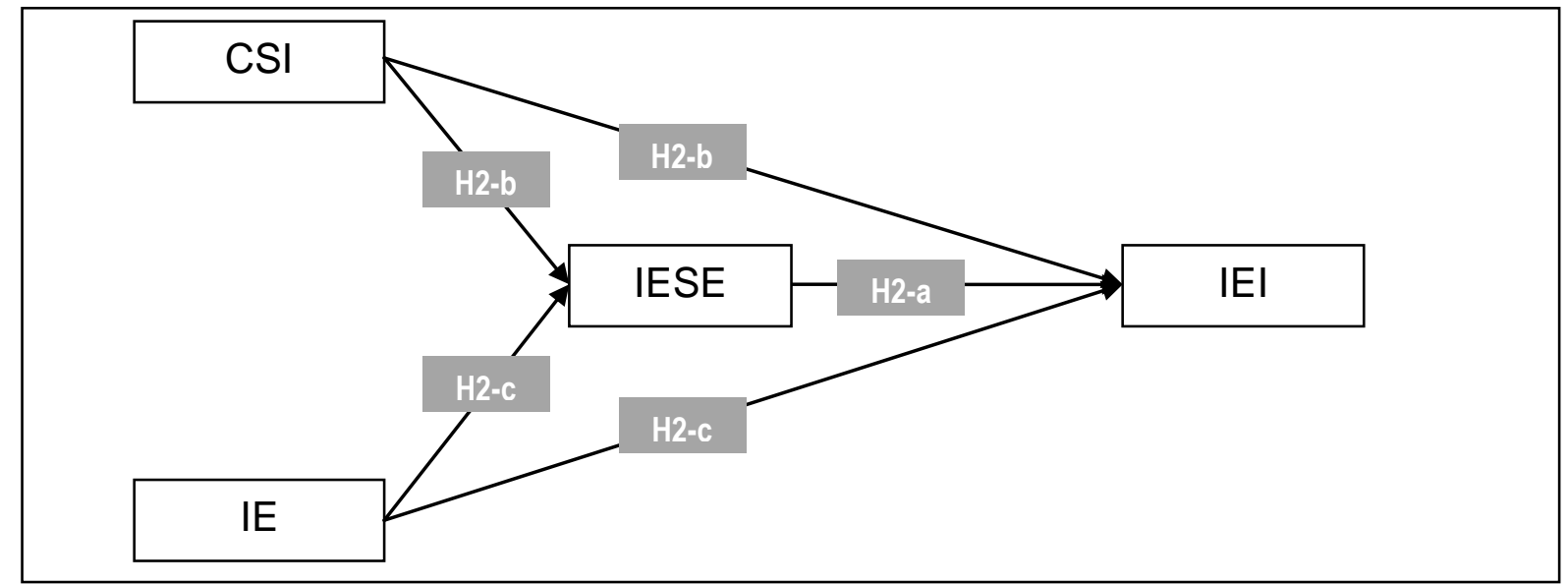

Figure 2. Research Model 2 (Planning Stage) partly based on based on Kickul et al. (2009); Sample of 111 students;

CSI = Cognitive Style Index according to Allinson \& Hayes (1996); IE = International Experience; IESE = International Entrepreneurial Self-Efficacy and IEI = International Entrepreneurial Intention (cf. Kickul et al., 2009)

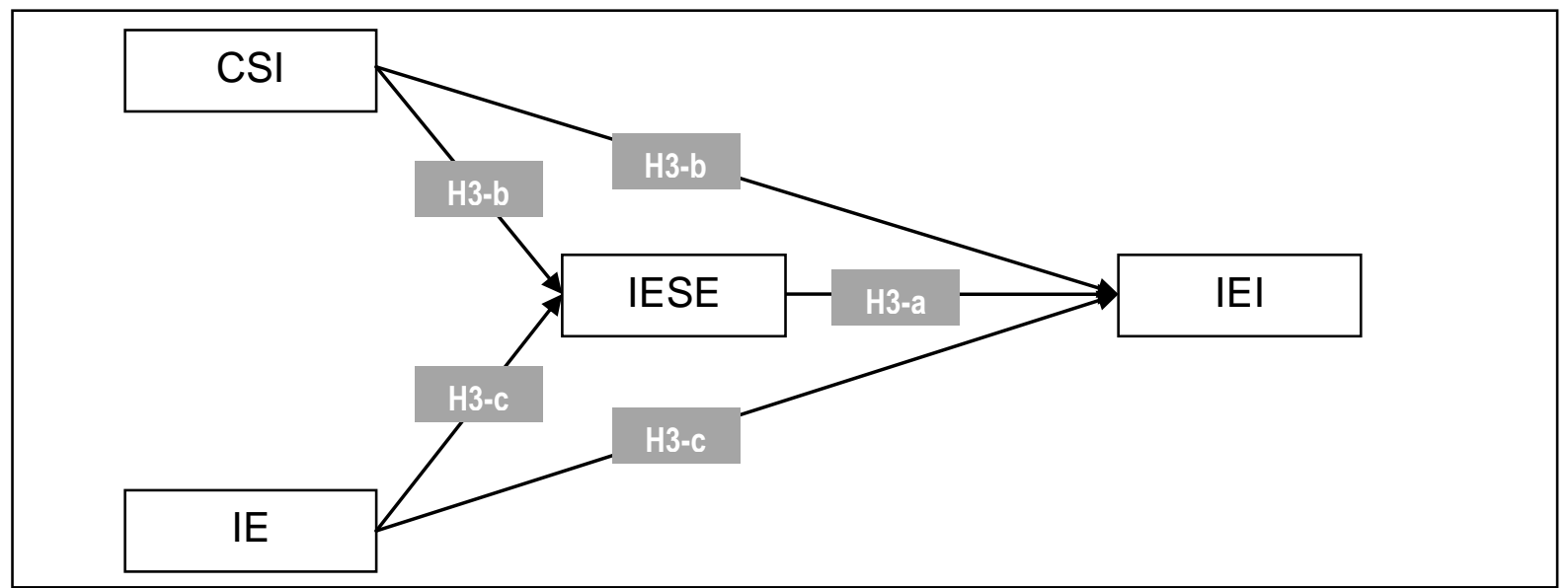

Figure 3. Research Model 3 (Marshalling Stage) partly based on Kickul et al. (2009); Sample of 111 students;

CSI = Cognitive Style Index according to Allinson \& Hayes (1996); IE = International Experience; IESE = International Entrepreneurial Self-Efficacy and IEI = International Entrepreneurial Intention (cf. Kickul et al., 2009) 


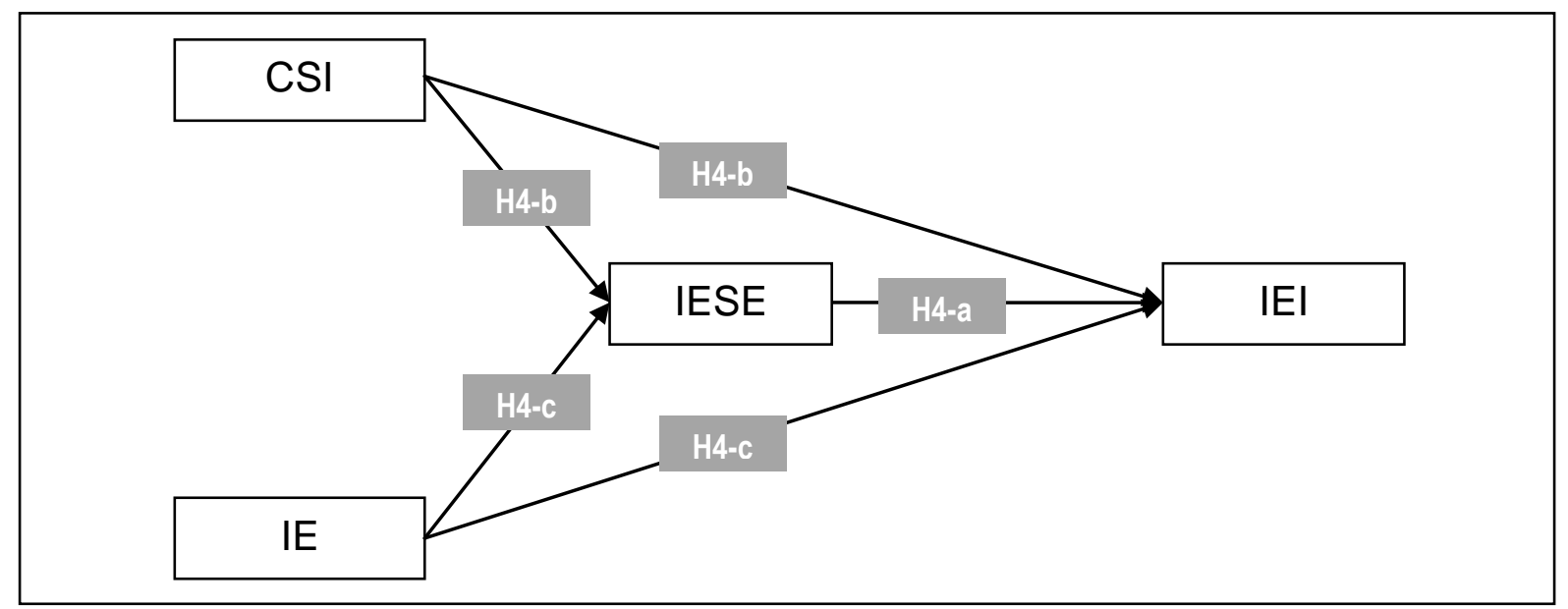

Figure 4. Research Model 4 (Implementing Stage) partly based on Kickul et al. (2009); Sample of 111 students;

CSI = Cognitive Style Index according to Allinson \& Hayes (1996); IE = International Experience; IESE = International Entrepreneurial Self-Efficacy and IEI = International Entrepreneurial Intention (cf. Kickul et al., 2009)

The research models were tested for identifiability (Weiber \& Mühlhaus, 2010):

Table 6. Identifiability of the Model

\begin{tabular}{lcccc}
\hline Criteria & $\begin{array}{c}\text { Research } \\
\text { Model 1 }\end{array}$ & $\begin{array}{c}\text { Research } \\
\text { Model 2 }\end{array}$ & $\begin{array}{c}\text { Research } \\
\text { Model 3 }\end{array}$ & $\begin{array}{c}\text { Research } \\
\text { Model 4 }\end{array}$ \\
\hline Number Sample Moments & 45 & 45 & 66 & 45 \\
Number of Parameters & 23 & 23 & 27 & 23 \\
Degree of Freedom (DF) & 22 & 22 & 39 & 22 \\
Chi-Square & 35.249 & 30.647 & 42.848 & 30.409 \\
Probability Level & $.036^{*}$ & .104 & .310 & .109 \\
CMIN/DF & 1.602 & 1.393 & 1.099 & 1.382 \\
Matrices & positive & positive & positive & positive \\
\hline
\end{tabular}

Note. AMOS 20 - Table by this author based on IBM Amos 20

The identifiability of all four models was attained, all matrices are positive. However, the probability level is statistically significant only in model 1. Models 2 and 4 failed marginally to attain statistical significance, model 3 failed with a considerable margin. Nevertheless, the statement must be interpreted with caution (Kline, 2011, pp. 199 et seqq.; Weiber \& Mühlhaus, 2010, pp. 160-161). Various authors refer to the fact that the Chi Square is applicable only to a limited extent for practical applications (= descriptive character) and should be used to assess the model fit of CMIN/DF, whereby its value is under 2.5, respectively 2.0, for 
a good model fit (Weiber \& Mühlhaus, 2010, p. 162). The above results show that all models attain this value. Further fit measurements for verifying the model will be used during the subsequent model verification (Weiber \& Mühlhaus, 2010).

The plausibility check figured out, whether "... implausible parameter estimates in the form of negative variances or communalities greater than 1" (Weiber \& Mühlhaus, 2010, p. 159) exist, which are called Heyword Cases (Weiber \& Mühlhaus, 2010). The research shows that there are no Heywood cases for models 1, 2, 3 and 4. The inferential quality criteria rootmean-square error of approximation (RMSEA) shows the following values for the model 1 to 4 (Weiber \& Mühlhaus, 2010):

Table 7. Inferential quality criteria

\begin{tabular}{lccccc}
\hline Criteria - Default Model & Guideline & $\begin{array}{c}\text { Research } \\
\text { Model 1 }\end{array}$ & $\begin{array}{c}\text { Research } \\
\text { Model 2 }\end{array}$ & $\begin{array}{c}\text { Research } \\
\text { Model 3 }\end{array}$ & $\begin{array}{c}\text { Research } \\
\text { Model 4 }\end{array}$ \\
\hline & & & & & \\
RMSEA & $\leq 0.08 *$ & 0.074 & 0.060 & 0.030 & 0.059 \\
\hline
\end{tabular}

* According to Brown and Cudeck cited in Weiber \& Mühlhaus, 2010

Note. AMOS 20 - Table by this author

The above values confirm a good model fit with regard to of the RMSEA value. The descriptive quality criteria root mean square residuals (RMR), goodness of fit index (GFI) and adjusted goodness of fit index (AGFI) shows the following values for the research models 1 to 4 (Weiber \& Mühlhaus, 2010):

Table 8. Descriptive quality criteria

\begin{tabular}{lccccc}
\hline $\begin{array}{l}\text { Criteria - Default Mo- } \\
\text { del }\end{array}$ & Guideline & $\begin{array}{c}\text { Research } \\
\text { Model 1 }\end{array}$ & $\begin{array}{c}\text { Research } \\
\text { Model 2 }\end{array}$ & $\begin{array}{c}\text { Research } \\
\text { Model 3 }\end{array}$ & $\begin{array}{c}\text { Research } \\
\text { Model 4 }\end{array}$ \\
\hline RMR & minimal & 0.290 & 0.285 & 0.306 & 0.291 \\
GFI & $\geq 0.9$ & 0.940 & 0.944 & 0.936 & 0.947 \\
AGFI & $\geq 0.9$ & 0.877 & 0.886 & 0.892 & 0.892 \\
\hline
\end{tabular}

Note. AMOS 20 - Table by this author; Guideline defined by Weiber \& Mühlhaus, 2010

The results indicate a good model fit for all models. The incremental fit was based on the normed fit index (NFI), the comparative fit index (CFI), and incremental fit index (IFI), for which Weiber and Mühlhaus defined the following guidelines (Weiber \& Mühlhaus, 2010): 
Table 9. Incremental fit

\begin{tabular}{lccccc}
\hline Criteria & Guideline & $\begin{array}{c}\text { Research } \\
\text { Model 1 }\end{array}$ & $\begin{array}{c}\text { Research } \\
\text { Model 2 }\end{array}$ & $\begin{array}{c}\text { Research } \\
\text { Model 3 }\end{array}$ & $\begin{array}{c}\text { Research } \\
\text { Model 4 }\end{array}$ \\
\hline $\begin{array}{l}\text { Normed Fit Index } \\
\text { (NFI) }\end{array}$ & $\geq 0.9$ & 0.901 & 0.910 & 0.919 & 0.922 \\
$\begin{array}{l}\text { Comparative Fit Index } \\
\text { (CFI) }\end{array}$ & $\geq 0.9$ & 0.959 & 0.972 & 0.992 & 0.976 \\
$\begin{array}{l}\text { Incremental Fit Index } \\
\text { (IFI) }\end{array}$ & $\geq 0.9$ & 0.960 & 0.973 & 0.992 & 0.977 \\
\hline
\end{tabular}

Note. AMOS 20 - Table by this author; Guideline defined by Weiber \& Mühlhaus, 2010

The above results met the expectation. To sum up, the results indicate a sufficient model fit all model 1 to 4 . Based on the confirmation of the reliability, validity and fit of research models 1, 2, 3 and 4 I continue now with the presentation of results. The first step based on a plausibility test and an evaluation of the parameters for the hypotheses by using the critical ratio values $(\mathrm{CR})$ with a standard value $\geq 1.96$ and a probability of error of $\mathrm{P}$ (Weiber \& Mühlhaus, 2010). The results for model 1 are illustrated in the following table:

Table 10. Test of hypotheses - Model 1

\begin{tabular}{lcccc}
\hline $\begin{array}{l}\text { Hypotheses Rese- } \\
\text { arch Model 1 }\end{array}$ & $\begin{array}{c}\text { C.R. } \\
(\geq 1.96)\end{array}$ & P & $\begin{array}{c}\text { Evaluation } \\
\text { Results }\end{array}$ \\
\hline H1a: & IESE - IEI & 1.922 & $0.055^{*}$ & Fulfilled \\
H1b: & CSI - IESE & -1.143 & 0.253 & Not Fulfilled \\
& CSI - IEI & 0.711 & 0.477 & Not Fulfilled \\
H1c: & IE - IESE & 0.178 & 0.858 & Not Fulfilled \\
& IE - IEI & 1.889 & $0.059^{*}$ & Fulfilled \\
\hline
\end{tabular}

The results show that only two hypotheses of model 1 have fulfilled the above mentioned parameters. The following figure illustrates the results by the standardized estimates for the research model 1: 


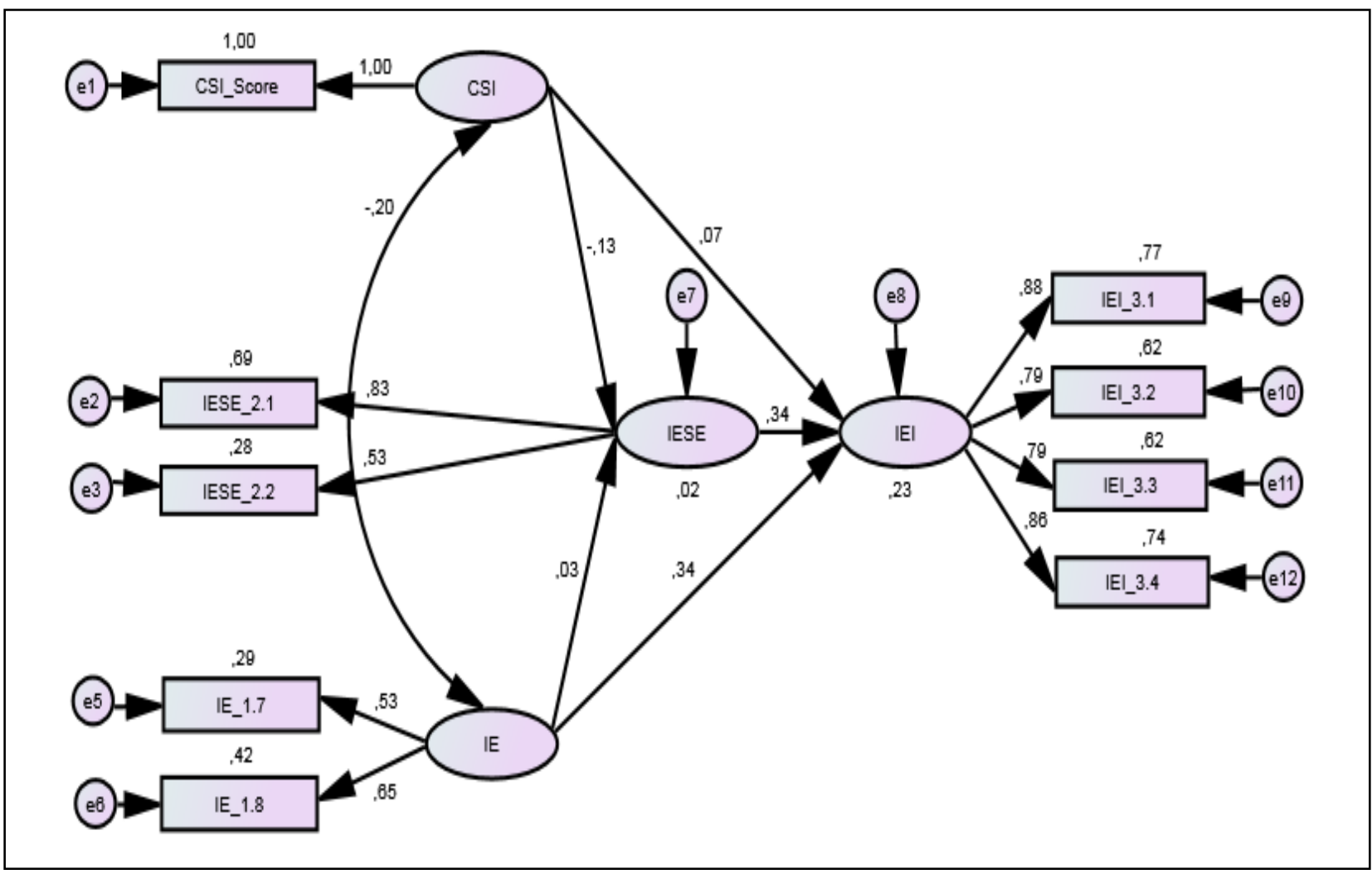

Figure 5. Research Model 1 (Searching Stage) partly based on Kickul et al. (2009); Sample of 111 students;

CSI = Cognitive Style Index according to Allinson \& Hayes (1996); IE = International Experience; IESE = International Entrepreneurial Self-Efficacy and IEI = International Entrepreneurial Intention (cf. Kickul et al., 2009); eX = Measurement error.

The review of the hypotheses $\mathrm{H} 1 \mathrm{a}, \mathrm{H} 1 \mathrm{~b}$ and $\mathrm{H} 1 \mathrm{c}$ for model 1 shows the following results:

1) The path coefficients (see Figure above) for IESE - IEI (H1a), IE - IESE (H1c), IE IEI (H1c) and CSI - IEI (H1b) are positive, which indicates that most the model estimate is consistent with the hypothetical relationship model for research model 1 . The path coefficient CSI - IESE (H1b) is negative.

2) The path coefficients values of IESE - IEI (H1a) and IE - IEI (H1c) are substantial, because both achieved a value of 0.34 which are greater than 0.2 (Weiber \& Mühlhaus, 2010). All other path coefficients are less than 0.2 and thus are not considered substantial.

3) The squared multiple correlation $\left(\mathrm{R}^{2}\right)$ shows that only $2 \%$ of the variance in IESE is explained by CSI and IE, whereas $23 \%$ of the variance in IEI is explained by IESE, 
CSI and IE. It could be concluded, that IESE and IE providing a convincing explanation.

The plausibility test and an evaluation of the parameters for model 2 show the following results:

Table 11. Test of hypotheses - Model 2

\begin{tabular}{llccc}
\hline $\begin{array}{l}\text { Hypotheses Rese- } \\
\text { arch Model 2 }\end{array}$ & $\begin{array}{c}\text { C.R. } \\
(\geq 1.96)\end{array}$ & P & $\begin{array}{c}\text { Evaluation } \\
\text { Results }\end{array}$ \\
\hline H2a: & IESE - IEI & 1.530 & 0.126 & Not Fulfilled \\
H2b: & CSI - IESE & -1.335 & 0.182 & Not Fulfilled \\
& CSI - IEI & 0.817 & 0.414 & Not Fulfilled \\
H2c: & IE - IESE & 1.169 & 0.243 & Not Fulfilled \\
& IE - IEI & 1.576 & 0.115 & Not Fulfilled \\
\hline
\end{tabular}

The results show that none hypotheses of model 2 have fulfilled the above mentioned parameters. The following figure illustrates the results by the standardized estimates for the research model 2:

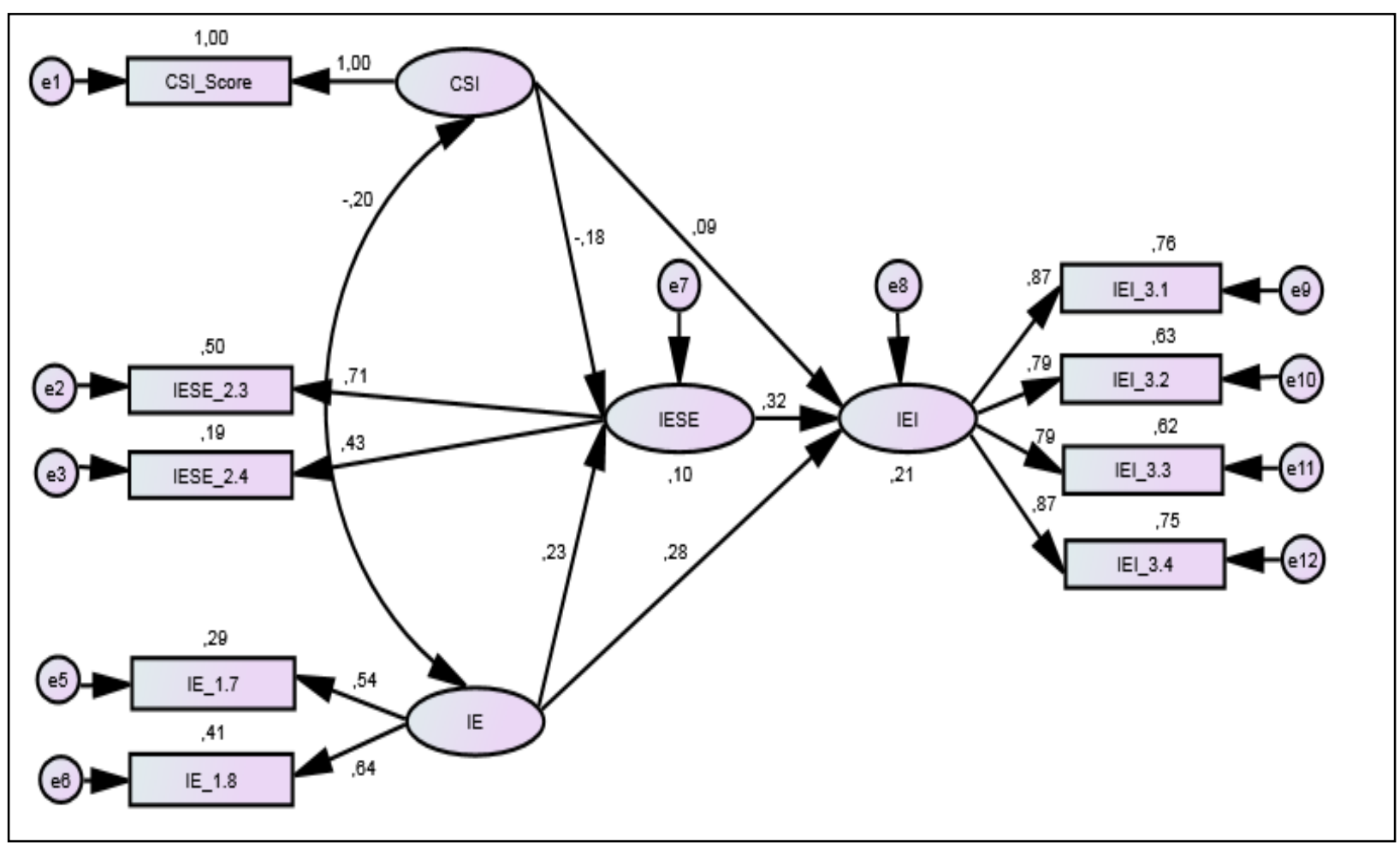

Figure 6. Research Model 2 (Planning Stage) partly based on Kickul et al. (2009); Sample of 111 students;

CSI = Cognitive Style Index according to Allinson \& Hayes (1996); IE = International Experience; IESE = International Entrepreneurial Self-Efficacy and IEI = International Entrepreneurial Intention (cf. Kickul et al., 2009); eX = Measurement error 
The review of the hypotheses $\mathrm{H} 2 \mathrm{a}, \mathrm{H} 2 \mathrm{~b}$ and $\mathrm{H} 2 \mathrm{c}$ for model 2 shows the following results:

1) The path coefficients for IESE - IEI (H2a), IE - IESE (H2c), IE - IEI (H2c) and CSI IEI (H2b) are positive, which indicates that most the model estimate is consistent with the hypothetical relationship model for research model 2. The path coefficient CSI IESE (H2b) is negative. The results of model 2 are comparable with model 1, but in contrast to model 1 not significant.

2) The path coefficients values of IESE - IEI (H2a) and IE - IEI (H2c) are substantial but not significant.

3) The squared multiple correlation $\left(\mathrm{R}^{2}\right)$ shows that $10 \%$ of the variance in IESE is explained by CSI and IE, whereas $21 \%$ of the variance in IEI is explained by IESE, CSI and IE. It could be concluded, that IESE and IE also providing in comparison to model 1 a convincing explanation, but the results are not significant.

The plausibility test and the evaluation of the parameters for model 3 are illustrated by the following table (Weiber \& Mühlhaus, 2010):

Table 12. Test of hypotheses - Model 3

\begin{tabular}{lcccc}
\hline $\begin{array}{l}\text { Hypotheses Rese- } \\
\text { arch Model 3 }\end{array}$ & $\begin{array}{c}\text { C.R. } \\
(\geq 1.96)\end{array}$ & P & $\begin{array}{c}\text { Evaluation } \\
\text { Results }\end{array}$ \\
\hline H3a: & IESE - IEI & 4.906 & $0.001^{* * *}$ & $\begin{array}{r}\text { Fulfilled } \\
\text { H3b: }\end{array}$ \\
CSI - IESE & -0.681 & 0.496 & Not Fulfilled \\
& CSI - IEI & 0.743 & 0.457 & Not Fulfilled \\
H3c: & IE - IESE & 0.173 & 0.863 & Not Fulfilled \\
& IE - IEI & 1.915 & $0.056^{*}$ & Fulfilled \\
\hline Note. AMOS 20 - Table by this author; Guideline defined by Weiber \& Mühlhaus, 2010
\end{tabular}

The results show that two hypotheses of model 3 have fulfilled the above mentioned parameters. These results are comparable with the results of model 1 . The following figure illustrates the results by the standardized estimates for the research model 3: 


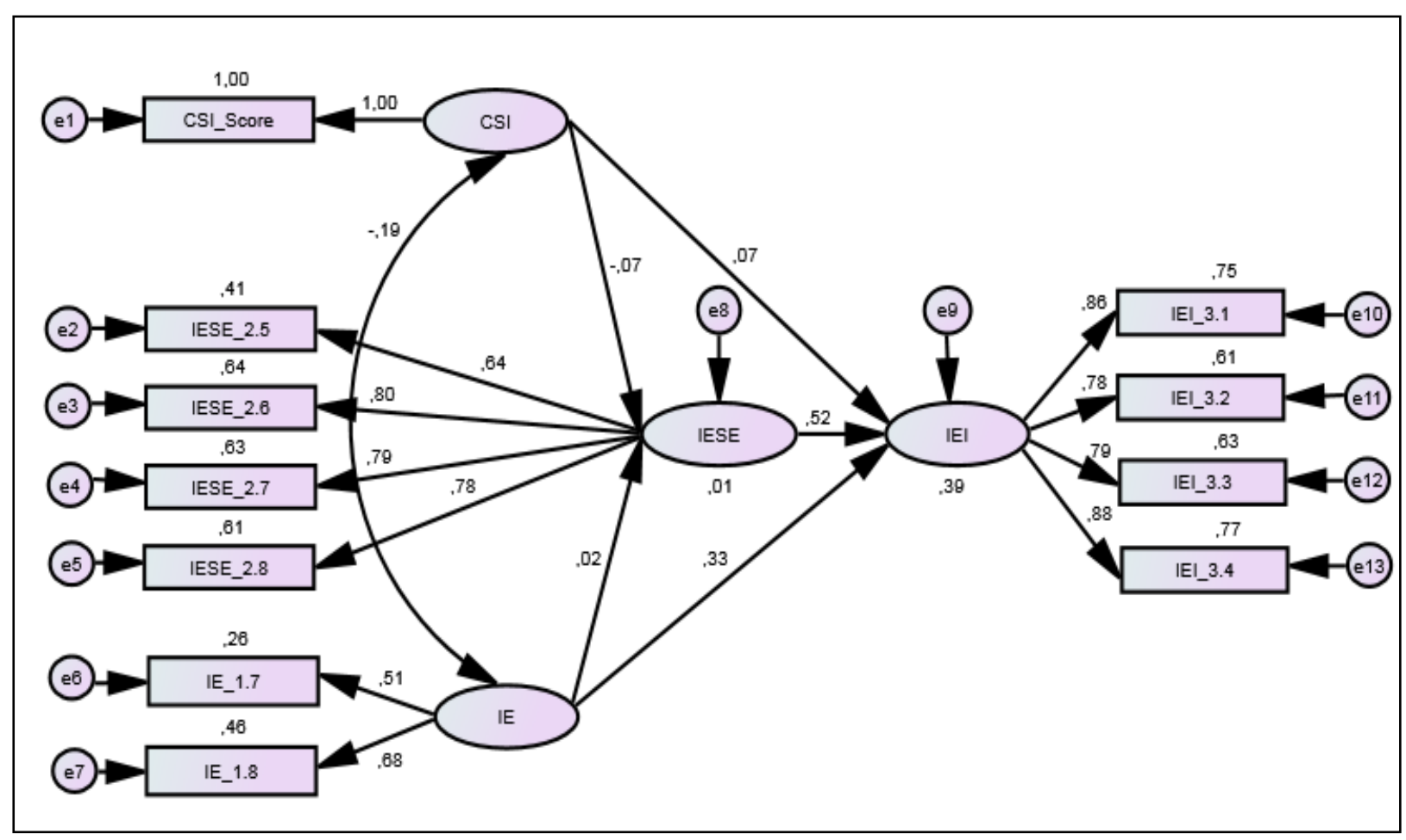

Figure 7. Research Model 3 (Marshalling Stage) partly based on Kickul et al. (2009); Sample of 111 students;

CSI = Cognitive Style Index according to Allinson \& Hayes (1996); IE = International Experience; IESE = International Entrepreneurial Self-Efficacy and IEI = International Entrepreneurial Intention (cf. Kickul et al., 2009); eX = Measurement error

The review of the hypotheses $\mathrm{H} 3 \mathrm{a}, \mathrm{H} 3 \mathrm{~b}$ and $\mathrm{H} 3 \mathrm{c}$ for model 3 shows the following results:

1) The path coefficients for IESE - IEI (H3a), IE - IESE (H3c), IE - IEI (H3c) and CSI IEI (H3b) are positive, which indicates that most the model estimate is consistent with the hypothetical relationship model for research model 1. The path coefficient CSI IESE (H3b) is negative. The results are comparable with model 1.

2) The path coefficients values of IESE - IEI (H3a) and IE - IEI (H3c) are substantial, they achieved a value of $0.52(\mathrm{H} 3 \mathrm{a})$ respectively $0.33(\mathrm{H} 3 \mathrm{c})$ which are greater than 0.2 (Weiber \& Mühlhaus, 2010). All other path coefficients are less than 0.2 and thus are not considered substantial.

3) The squared multiple correlation $\left(\mathrm{R}^{2}\right)$ shows that only $1 \%$ of the variance in IESE is explained by CSI and IE, whereas $39 \%$ of the variance in IEI is explained by IESE, CSI and IE. It could be concluded, that IESE and IE providing a convincing explanation. Also this results are comparable with model 1. 
The last plausibility test and evaluation of the parameters concerned with model 4 (see table below):

Table 13. Test of hypotheses - Model 4

\begin{tabular}{lcccc}
\hline $\begin{array}{l}\text { Hypotheses Rese- } \\
\text { arch Model 4 }\end{array}$ & $\begin{array}{c}\text { C.R. } \\
(\geq 1.96)\end{array}$ & $\mathrm{P}$ & $\begin{array}{c}\text { Evaluation } \\
\text { Results }\end{array}$ \\
\hline H4a: & IESE - IEI & 3.843 & $0.001 * * *$ & Fulfilled \\
H4b: & CSI - IESE & -0.297 & 0.767 & Not Fulfilled \\
& CSI - IEI & 0.385 & 0.700 & Not Fulfilled \\
H4c: & IE - IESE & 0.083 & 0.934 & Not Fulfilled \\
& IE - IEI & 1.756 & 0.079 & Not Fulfilled \\
\hline
\end{tabular}

Note. AMOS 20 - Table by this author; Guideline defined by Weiber \& Mühlhaus, 2010

The results show that only one hypotheses of model 4 has fulfilled the above mentioned parameters and another one has almost fulfilled the parameter (H4c / IE - IEI). The following figure illustrates the results by the standardized estimates for the research model 4:

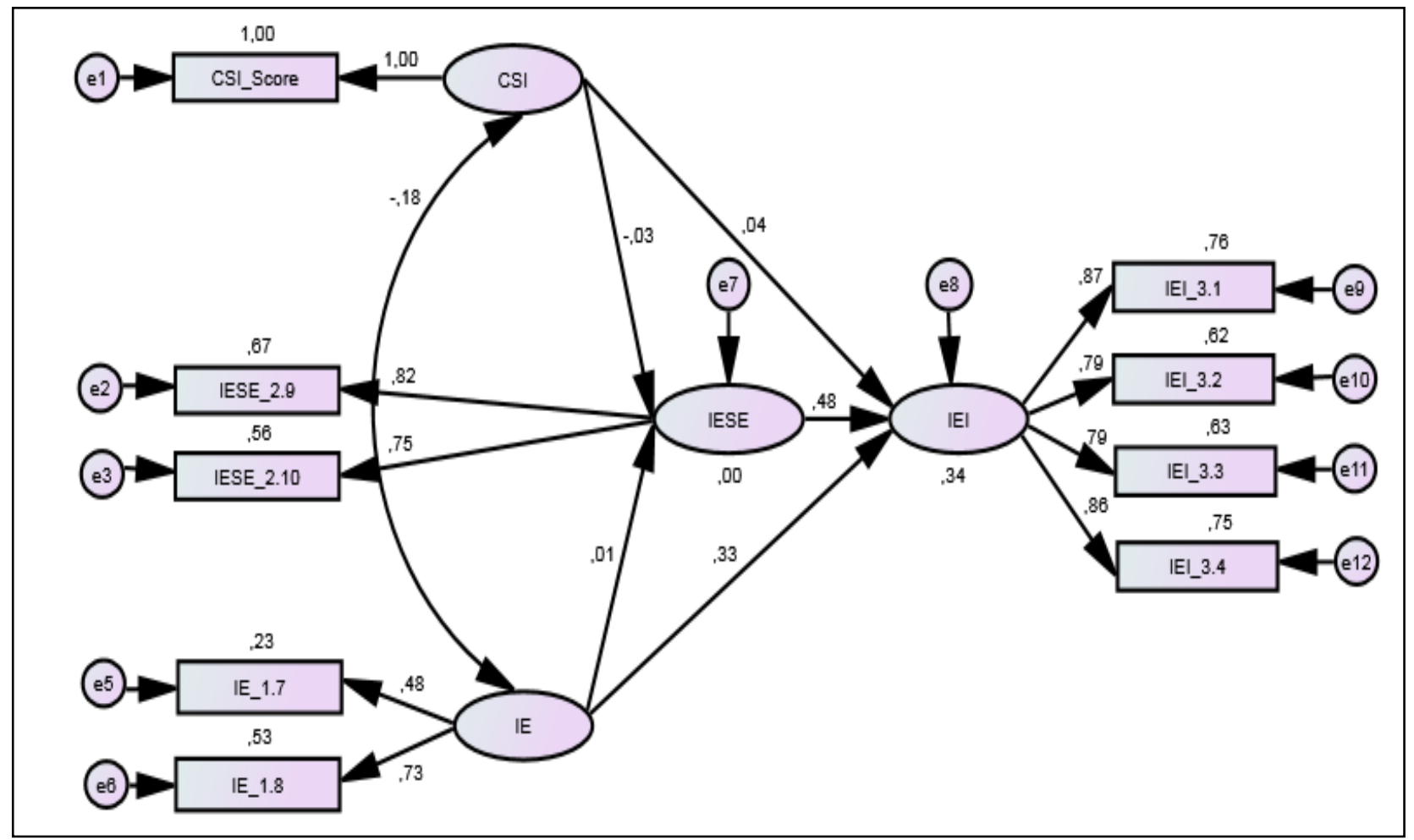

Figure 8. Research Model 4 (Implementing Stage) partly based on Kickul et al. (2009); Sample of 111 students;

CSI = Cognitive Style Index according to Allinson \& Hayes (1996); IE = International Experience; IESE = International Entrepreneurial Self-Efficacy and IEI = International Entrepreneurial Intention (cf. Kickul et al., 2009); eX = Measurement 
The review of the hypotheses $\mathrm{H} 4 \mathrm{a}, \mathrm{H} 4 \mathrm{~b}$ and H4c for model 4 shows the following results:

1) The path coefficients for IESE - IEI (H4a), IE - IESE (H4c), IE - IEI (H4c) and CSI IEI (H4b) are positive, which indicates that most the model estimate is consistent with the hypothetical relationship model for research model 4 . The path coefficient CSI IESE (H4b) is negative. The results of model 4 are comparable with model 1 and 3, but on a lower level of significance.

2) The path coefficients values of IESE - IEI (H4a) and IE - IEI (H4c) are substantial and partly significant $(\mathrm{H} 4 \mathrm{a})$.

3) The squared multiple correlation $\left(\mathrm{R}^{2}\right)$ shows that $0 \%$ of the variance in IESE is explained by CSI and IE, whereas $34 \%$ of the variance in IEI is explained by IESE, CSI and IE. Again it could be concluded, that IESE and IE providing a convincing explanation.

\section{Discussion}

Based on the above results, the following findings can be formulated with regard to the Hypotheses. Model 1 is characterised by an adequate model fit, whereby only parts of the relationships surveyed were significant. The assessment of normality shows no remarkable characteristics:

Hypothesis H1a: The study results for H1a (Model 1 - Searching Stage) can be seen as a confirmation of the findings from Kickul et al. (2009), since, in an international context too, a positive, significant and substantial relationship between Entrepreneurial Self-Efficacy and Entrepreneurial Intention - in other words, IESE and IEI - was confirmed in the Searching Stage (Kickul et al., 2009, p. 448). In plain words, students in the "Searching Stage" that have more International Entrepreneurial Self-Efficacy have a higher value in International Entrepreunerial Intention, too. In this respect, the hypothesis can be regarded as confirmed.

Hypothesis H1b: In this case, via the structural equation model (Model 1 - Searching Stage), the results did not provide any confirmation for the students' Cognitive Style (CSI) influencing IESE or IEI. The values were neither significant nor substantial. It should be noted here that, on the one hand, Kickul et al. (2009) acquired data on Cognitive Style using a different method from that in this study, and on the other hand, did 
not study data in an international context (Kickul et al., 2009, p. 445). The intuitive cognitive style assumed by the authors could not be proven, however; the path coefficient CSI - IESE shows a negative value at - 0.13, which at least argues against the basic assumption in model 1 , which assumes that the study was made using the analytic cognitive style; in other words, the intuitive style was probably used. Following this a students' IESE and IEI is not influenced by his or her way of thinking, at least not in a statistically relevant way. In this respect, further research is required, in other words, H1b cannot be confirmed.

Hypothesis H1c: The object of this hypothesis (Model 1 - Searching Stage) was the question as to what extent International Experience (IE) influences IESE or IEI. The results confirm the assumption that IE affects IEI positively to a significant and substantial extent. This conforms to different studies made during the past few years which assume direct influence of experience on intentions (cf. Sommer, 2011) and in contrast to the Theory of Planned Behavior from Ajzen (1985; 1991; 2005). Furthermore, the influence of IE on IESE could be confirmed, which was also positive, significant and substantial. These results did not surprise, because positive International Experience (IE) could provide a necessary basis for continuing a potential career as an international entrepreneur, particularly in the Searching Stage of IESE or IEI. The ability to classify opportunities and risks based on one's own International Experiences (IE) represents a value in itself, which cannot be adequately compensated for, or only partially, by theoretical knowledge acquired through learning. Therefore the vital importance of experience gained abroad for a student's further international career is underlined. In total, H1c can be confirmed.

Model 2 is characterised by an adequate model fit, however, none of the relationships studied was significant. The assessment of normality showed no remarkable characteristics:

Hypothesis H2a: By analogy with $\mathrm{H} 1 \mathrm{a}$, a study was made as to whether there is also a positive relationship between IESE and IEI in model 2 - Planning Stage - in other words, if the results from Kickul et al. (2009) could be confirmed. The results show that model 2 did not provide any significant results and therefore H2a could not be confirmed, whereby the significance value deviated moderately at 0.126 . 
Hypothesis $\mathrm{H} 2 \mathrm{~b} / \mathrm{H} 2 \mathrm{c}$ : In this case also, confirmation of the hypotheses is not possible due to the absence of significance. At 0.115 , the significance value deviated only moderately for a possible relationship between IE and IEI; for the other relationships studied, the deviation was considerable.

Model 3 is characterised by an adequate model fit, whereby only parts of the relationships studied were significant. The assessment of normality showed no remarkable characteristics:

Hypothesis H3a: Using model 3, a study was carried out as to whether a positive relationship between IESE and IEI exists, with reference to the Marshalling Stage (Kickul et al., 2009, pp. 444-450). The existing results conform to those of Kickul et al. (2009), according to which a positive, highly significant and substantial relationship, also in an international context, exists between Entrepreneurial Self-Efficacy and Entrepreneurial Intention - here IESE and IEI. In this regard, the hypothesis can be regarded as definitely confirmed.

Hypothesis H3b: The object of this hypothesis - with reference to the Marshalling Stage - is the question of the possible influence of the Cognitive Style on IESE or IEI; following Kickul et al. (2009), the results documented that “...individuals with the analytic preferred mode of thinking reported greater entrepreneurial self-efficacy for planning, marshalling of resources, and implementation stages of the venture creation process" (Kickul et al., 2009, p. 448). The results of the present study with an international context cannot confirm this statement. The relationship between the CSI Index and the IESE and also that between the CSI Index and the IEI were neither significant nor substantial. In this respect, hypothesis $\mathrm{H} 3 \mathrm{~b}$ must be discarded.

Hypothesis H3c: In a way similar to hypothesis H1c, confirmation could be made also in the Marshalling Stage that there is a positive, significant and substantial relationship between IE and IEI. However, no significant and substantial relationship between IE and IESE could be established. With regard to IE - IEI , the results can be interpreted to the effect that in the Marshalling Stage too, personal International Experiences (IE) can exercise a positive, direct influence on the formation of intention, because these can reduce possible constraints (e.g. uncertainty) when the intention is being formed (Sommer, 2011, Sommer, 2013). The absence of a relationship between IE - IESE is 
possibly due to the fact that parts of the tasks described there, such as e.g. raise money (Kickul et al., 2009, p. 450) are less contextual. Obtaining money - with reference to a national or international context - differs possibly only minimally from the point of view of those surveyed. In total, it can be ascertained that hypothesis H1c can be confirmed in reference to the relationship IE - IEI.

Model 4 is characterised by an adequate model fit, whereby only parts of the relationships studied were significant. The assessment of normality showed no special characteristics: Hypothesis H4a: In the framework of the last model too - the Implementing Stage the relationship between IESE and IEI can be confirmed. The relationship is positive, significant and substantial, as in model 1 and 3.

Hypothesis $H 4 b$ : Here too, as in model 1 and 3, no confirmation can be made of a positive, significant and substantial relationship between CSI and IESE or CSI and IEI. Hypothesis $H 4 b$ can't be seen as confirmed.

Hypothesis H4c: The results of Hypothesis H4c show that in the Implementing Stage there is a significant relationship, to a limited extent, between IE and IEI at $p=0.079$. With regard to the relationship IE and IESE there was no significant relationship. In total, all the results appear to indicate that IE in the Implementing Stage have a low level of relevance, based on tasks asked about (Kickul et al., 2009, p. 450). Therefore, hypothesis $\mathrm{H} 4 \mathrm{c}$ can be partly seen as confirmed.

Summarising, the following Implication can be given: (1) Using models 1, 3 and 4, a positive, significant and substantial relationship between IESE and IEI (= H1a, H3a and H4a) could be confirmed, which is in accordance with Kickul et al. (2009). Model 2 did in fact provide no significant results, but the deviation was moderate; (2) With regard to a possible relationship between CSI and IESE or IEI (= H1b, H2b, H3b and H4b) it could be inferred that a positive, significant and substantial relationship did not exist in any model, which contradicts the results from Kickul et al. (2009). The reason for this can be found in the way CSI is acquired, which, in the present study, deviated from the method recommended by Kickul et al. (2009). In the literature there are differing views as to the way in which data is collected (Allinson \& Hayes, 1996; Backhaus \& Liff, 2007; Cools \& van den Broeck, 2007; Sadler-Smith, Spicer, \& Tsang, 2000) and this possibly has a significant influence on the results, making 
clear the necessity of further scientific discussion:“...in our view, where the major problem in entrepreneurial cognition research is the evaluation of entrepreneurial thinking processes“" (Smith, Mitchell, \& Mitchell, 2009, p. 837). In addition, the question must be asked as to which Cognitive Style really makes an entrepreneur, e.g. Armstrong and Hird (2009) arrive at the conclusion that entrepreneurs tend to take an intuitive style (Armstrong \& Hird, 2009), which in part contradicts Kickul et al. (2009) and Barbosa et al. (2007). The present study results at least do not indicate that a certain Cognitive Style is to be preferred in academic education in the entrepreneurial sector. Rather, the results indicate that both styles are needed, which does not contradict Kickul et al. (2009), if one disregards the strict division into stages. The result can also be interpreted a challenge to promote students' creative competencies in academic education in the sense of Hamidi et al. (2008), in order to give the intuitive cognitive style more emphasis compared to the analytic style; (3) With regard to the relationship IE and IESE, respectively IEI, it was ascertained that for models 1 to 4 , no significant results could be achieved with regard to IE - IESE. Regarding the relationship IE - IEI, however, there were significant results for model 1 and $3\left(=0.059^{*}\right.$ resp. $\left.0.056^{*}\right)$ and significant results for model 2 and 4 , to a limited extent (=0.115 resp. 0.079). This indicates that more or less in all models or stages, IE positively promotes the formation of intention. On the one hand, this is in contrast to the assumptions made by Ajzen $(1985 ; 1991 ; 2005)$, who allocates to experience the role of a background factor only (Ajzen, 2005, p. 136), but on the other hand, is consistent with a number of studies on the group of themes experience and TPB according to Ajzen (1985) in general - such as that documented in an overview by Sommer (2011) - and entrepreneurial research in particular (Hamidi et al., 2008, p. 318). In special, complex contexts such as international entrepreneurship, which is essentially comprised of two contexts internationality and entrepreneurship - the meaningfulness of considering International Experience (IE) as a further determinant of the TPB model is shown. The TPB model is optimised by experience now being included in the main context of entrepreneurship and at the same time experience of the superordinate context internationality not being overlooked.

Furthermore, the following additional specific implications for Academic Education (AE) can be derived: (1) Promotion of international entrepreneurship can be supported by IE being gained early, e.g. supporting students during their studies; (2) A combination of theory and practice is desirable also for international entrepreneurship; (3) IE do not have to be oriented towards certain circumstances (e.g. raising money during the Marshalling Stage), to nevertheless positively affect a subsequent International Entrepreneurial Intention (IEI). This 
speaks in favour of a balance in Academic Education (AE), which, despite all its details (e.g. raising money) should not allow its environment (e.g. intercultural knowledge) to be overlooked.

\section{Limitation}

The following limitation is at the basis of the study: (1) the sample size was relatively low at 111 study participants; (2) The study participants were all students who only represent up part of the potential entrepreneurs. It would be better to expand the study to other classes of society; (3) There is not necessarily a connection between intention and behavior, as different studies have shown (cf. Ajzen, 2005); (4) The CSI Score was collected by deviating from the study made by Kickul et al. (2009), so that a direct comparison of the results is not given. In addition, another context was studied, by deviating from Kickul et al. (2009). In this respect, more research is needed as to the extent to which different types of CSI collection influence the result. The authors Kickul et al. (2009) already refer to variety (Kickul et al., 2009, p. 445). Here, reference is made to work carried out by Cools et al. (2007), amongst others, who differentiate between different Styles; (5) The focus of this study was on the variables CSI and IE. Subsequent studies should extend the spectrum of variables; (6) The random sample was possibly inhomogeneous due to different European nationalities being included. Subsequent studies should counter this aspect by selecting a random sample of study participants from one country. 


\section{References}

Ajzen, I. (1985). From Intention to Action: A Theory of Planned Behavior. In J. Kuhl \& J. Beckmann (Eds.), Springer series in social psychology. Action control: From cognition to behavior (pp. 11-39). Berlin: Springer.

Ajzen, I. (1991). The theory of planned behavior. Organizational Behavior and Human Decision Processes, 50(2), 179-211. doi:10.1016/0749-5978(91)90020-T

Ajzen, I. (2005). Attitudes, personality and behavior (2nd ed.). Mapping social psychology. Maidenhead: Open Univ. Press.

Albarracín, D., \& Wyer, R. S. (2000). The cognitive impact of past behavior: Influences on beliefs, attitudes, and future behavioral decisions. Journal of Personality and Social Psychology, 79(1), 5-22. doi:10.1037/0022-3514.79.1.5

Allinson, C. (2010, January 11). Cognitive Style Index [e-Mail], The University of Leeds, Leeds, UK

Allinson, C. W., \& Hayes, J. (1996). The Cognitive Style Index: A Measure of IntuitionAnalysis For Organizational Research. Journal of Management Studies, 33(1), 119135. doi:10.1111/j.1467-6486.1996.tb00801.x

Armstrong, S. J., \& Hird, A. (2009). Cognitive Style and Entrepreneurial Drive of New and Mature Business Owner-Managers. Journal of Business and Psychology, 24(4), 419430. doi:10.1007/s10869-009-9114-4

Backhaus, K., \& Liff, J. P. (2007). Cognitive Style Index: Further investigation of the factor structure with an American student sample. Educational Psychology, 27(1), 21-31. doi:10.1080/01443410601061348

Bandura, A. (1994). Self-Efficacy. Retrieved from http://www.uky.edu/ eushe2/Bandura/ BanEncy.html

Barbosa, S. D., Gerhardt, M. W., \& Kickul, J. R. (2007). The Role of Cognitive Style and Risk Preference on Entrepreneurial Self-Efficacy and Entrepreneurial Intentions. Journal of Leadership \& Organizational Studies, 13(4), 86-104. doi:10.1177/10717919070130041001

Cambridge University Press. (2013). Cambridge Dictionaries Online. Retrieved from http://dictionary.cambridge.org 
The Influence of Experience and Cognitive Style on International Entrepreneurial Intentions: The Contribution of Academic Education in this Relation

Cools, E., \& van den Broeck, H. (2007). Development and Validation of the Cognitive Style Indicator. The Journal of Psychology, 141(4), 359-387. doi:10.3200/JRLP.141.4.359388

Cox, L. W., Mueller, S. L., \& Moss, S. E. (2002). The Impact of Entrepreneurship Education on Entrepreneurial Self-Efficacy. International Journal of Entrepreneurship Education, 1(2), 229-247.

Crant, J. M. (1996). The proactive personality scale as a predictor of entrepreneurial intentions. Journal of small business management, 34, 42-49

De la Fuente, J., Vera, M. M., \& Cardelle-Elawar, M. (2012). Contributions to Education from the Psychology of Innovation and Entrepreneurship, in Today's Knowledge Society. Electronic Journal of Research in Educational Psychology, 10(3), 942-966. Retrieved from http://investigacion-psicopedagogica.org/revista/new/ english/Contador Articulo.php?772

European University Cyprus. (2009). Cross-Cultural Management-Erasmus Intensive Programme. Retrieved from http://www.euc.ac.cy/easyconsole.cfm/id/895

Gollwitzer, P. M. (1993). Goal achievement: The role of intentions. München: Max-PlanckInst. für Psychologische Forschung.

Hamidi, D. Y., Wennberg, K., \& Berglund, H. (2008). Creativity in entrepreneurship education. Journal of Small Business and Enterprise Development, 15(2), 304-320. doi:10.1108/14626000810871691

Hird, A. P. (2012). The impact of entrepreneurial cognition on the founding and survival of new small businesses. Industry and Higher Education, 26(6), 453-460. doi:10.5367/ihe.2012.0124

Hsu, C.-L., \& Lu, H.-P. (2004). Why do people play on-line games? An extended TAM with social influences and flow experience. Information \& Management, 41(7), 853-868. doi:10.1016/j.im.2003.08.014

Katz, J. A., \& Shepherd, D. A. (2003). Cognitive Approaches to Entrepreneurship Research. In J. A. Katz \& D. A. Shepherd (Eds.), Advances in Entrepreneurship, Firm Emergence and Growth. Cognitive Approaches to Entrepreneurship Research (pp. 1-10). Bingley: Emerald (MCB UP ). doi: 10.1016/S1074-7540(03)06001-X

Kickul, J., Gundry, L. K., Barbosa, S. D., \& Whitcanack, L. (2009). Intuition Versus Analysis? Testing Differential Models of Cognitive Style on Entrepreneurial Self-Efficacy 
and the New Venture Creation Process. Entrepreneurship Theory and Practice, 33(2), 439-453. doi:10.1111/j.1540-6520.2009.00298.x

Kim, B., Choi, M., \& Han, I. (2009). User behaviors toward mobile data services: The role of perceived fee and prior experience. Expert Systems with Applications, 36(4), 85288536. doi:10.1016/j.eswa.2008.10.063

Kline, R. B. (2011). Principles and practice of structural equation modeling (3rd ed.). New York: Guilford Press.

Olson, P. (1985). Entrepreneurship: Process and Abilities. American Journal of Small Business, (10), 25-32.

Ouellette, J. A., \& Wood, W. (1998). Habit and intention in everyday life: The multiple processes by which past behavior predicts future behavior. Psychological Bulletin, 124(1), 54-74. doi:10.1037/0033-2909.124.1.54

Oxford University Press. (2013). Oxford Dictionaries. Retrieved from http://oxforddictionaries.com/

Pomery, E. A., Gibbons, F. X., Reis-Bergan, M., \& Gerrard, M. (2009). From Willingness to Intention: Experience Moderates the Shift From Reactive to Reasoned Behavior. Personality and Social Psychology Bulletin, 35(7), 894-908. doi:10.1177/0146167209335166

Sadler-Smith, E., Spicer, D. P., \& Tsang, F. (2000). Validity of the Cognitive Style Index: Replication and Extension. British Journal of Management, 11(2), 175-181. doi:10.1111/1467-8551.t01-1-00159

Sánchez, J. C., Carballo, T., \& Gutiérrez, A. G. (2011). The Entrepreneur from a Cognitive Approach. Psicothema, 23(3), 433-438. Retrieved from http://www.psicothema.com /pdf/3906.pdf

Sander, P., \& Sanders, L. (2003). Measuring confidence in academic study: A summary report. Electronic Journal of Research in Educational Psychology, 1(1), 1-17. Retrieved from http://www.investigacion-psicopedagogica.org/revista/articulos/1/ english/Art_1_1.pdf

Schmid, S., \& Kretschmer, K. (2005). How international are german supervisory boards? an exploratory study. Berlin: ESCP-EAP, Europäische Wirtschaftshochschule.

Sheeran, P., \& Orbell, S. (1999). Implementation intentions and repeated behaviour: augmenting the predictive validity of the theory of planned behaviour. European Journal of 
The Influence of Experience and Cognitive Style on International Entrepreneurial Intentions: The Contribution of Academic Education in this Relation

Social Psychology, 29(2-3), 349-369. doi:10.1002/(SICI)10990992(199903/05)29:2/3<349::AID-EJSP931>3.0.CO;2-Y

Smith, J. B., Mitchell, J. R., \& Mitchell, R. K. (2009). Entrepreneurial Scripts and the New Transaction Commitment Mindset: Extending the Expert Information Processing Theory Approach to Entrepreneurial Cognition Research. Entrepreneurship Theory and Practice, 33(4), 815-844. doi:10.1111/j.1540-6520.2009.00328.x

Sommer, L. (2010). Internationalization processes of small- and medium-sized enterprises - a matter of attitude? Journal of International Entrepreneurship, 8(3), 288-317. doi:10.1007/s10843-010-0052-z

Sommer, L. (2011). The theory of planned behaviour and the impact of past behaviour. International business and economics research journal, 10(1), 91-110.

Sommer, L. (2012). The Measurement of International Experience as a Dimension of Board Indices: Concept for an Improvement. International Journal of Business Administration, 3(4). doi:10.5430/ijba.v3n4p2

Sommer, L. (2013). The Influence of Action Control, Procrastination and Experience on Students' Goal Intention and Implementation Intention. Unpublished Paper, AlbstadtSigmaringen University, Albstadt, Germany

Urban, B. (2012). Researching entrepreneurship from a cognitive perspective:: A focus on necessity entrepreneurs in the Johannesburg area. African Journal of Business Management, 6(48), 11732-11742. Retrieved from http://www.academicjournals.org/AJBM/PDF/pdf2012/5Dec/Urban.pdf

Weiber, R., \& Mühlhaus, D. (2010). Strukturgleichungsmodellierung: Eine anwendungsorientierte Einführung in die Kausalanalyse mit Hilfe von AMOS, SmartPLS und SPSS ; [Extras im Web]. Springer-Lehrbuch. Heidelberg: Springer. 


\section{Appendix}

\section{Questionnaire:}

1. Personal Background-Questions (Source: Schmid \& Kretschmer, 2005; Sommer, 2012 modified and supplemented by the author)
PB-1.1:
Age
PB-1.2:
Sex
PB-1.3:
Please indicate your country of birth.
PB-1.4:
What degree are you studying for?
PB-1.5:
In which country have you been living for most of your life?
IE-1.6:
For how many years have you been living abroad?
$\underline{\text { IE-1.7: }}$
For how many years have you been working abroad (e.g. in terms of internships)?
IE-1.8:
For how many years have you been studying abroad?
IE-1.9: What country do you feel you belong to the most in terms of culture?

2. International Entrepreneurial Self-Efficacy - Questions (Source: Cox et al., 2002 cited by Kickul et al., 2009, p. 450 - modified by the author)

In this section, several tasks associated with founding an international business are listed.

Please indicate for each of them how confident you are of mastering these tasks ( 1 - not confident, 7 - completely confident).

IESE-2.1: Conceive a unique idea for an international business.

IESE-2.2: Identify market opportunities in foreign markets for a new business.

IESE-2.3: $\quad$ Plan a new, internationally active business.

IESE-2.4: $\quad$ Write a formal business plan.

IESE-2.5: Raise money to start an internationally active business.

IESE-2.6: Convince others to invest in your internationally active business.

IESE-2.7: Convince a bank to lend you money to start an internationally active business.

IESE-2.8: Convince others to work for you in your new internationally active business.

IESE-2.9: $\quad$ Manage a small, internationally active business.

IESE-2.10: Grow a successful internationally active business.

3. Propensity to found own business - Questions (Source: Crant, 1996; Kickul et al., 2009, p. 446- modified by the author)

Please indicate to which extent you agree to the following statements ( 1 - strongly disagree; 7 - strongly agree).

IEI-3.1: I will probably own my own internationally active business one day

IEI-3.2: It is likely that I will personally own a small internationally active business in the relatively near future.

IEI-3.3: $\quad$ Being 'my own boss' is an important goal of mine

IEI-3.4: $\quad$ I often think of having my own internationally active business.

4. Cognitive Style (Source: C. Allinson, personal communication, January 11, 2010; Allinson \& Hayes, 1996)

CSI-1 to 38: It is forbidden to reproduce more than 5 items in any form! For details please contact the above mentioned authors directly. 